\title{
Some Remarks on the Islamic and the Secular Paradigms of Knowledge
}

\author{
Ṭāhā J. al 'Alwān̄ì
}

By the time secularist thought had succeeded, at an intellectual level, in challenging the authority of the Church, its roots had already taken firm hold in western soil. Later, when western political and economic systems began to prevail throughout the world, it was only natural that secularism, as the driving force behind these systems, should gain ascendency worldwide. In time, and with varying degrees of success, the paradigm of positivism gradually displaced traditional and religious modes of thinking, with the result that generations of third world thinkers grew up convinced that the only way to "progress" and reform their societies was the way of the secular West. Moreover, since the experience of the West was that it began to progress politically, economically, and intellectually only after the influence of the Church had been marginalized, people in the colonies believed that they would have to marginalize the influence of their particular religions in order to achieve a similar degree of progress. Under the terms of the new paradigm, turning to religion for solutions to contemporary issues is an absurdity, for religion is viewed as something from humanity's formative years, from a "dark" age of superstition and myth whose time has now passed. As such, religion has no relevance to the present, and all attempts to revive it are doomed to failure and are a waste of time.

Many have supposed that it is possible to accept the western model of a secular paradigm while maintaining religious practices and beliefs. They reason that such an acceptance has no negative impact upon their daily lives so long as it does not destroy their places of worship or curtail their right to religious freedom. Thus, there remains hardly a contemporary community that has not fallen under the sway of this paradigm. Moreover, it is this paradigm that has had the greatest influence on the way different peoples perceive life, the universe, and the role of humanity as well as providing them with an alternative set of beliefs (if needed) and suggesting answers to the ultimate questions.

Țāhā J. al Alwānī is a member of the Fiqh Academy of the Organization of the Islamic Conference, chairman of the Fiqh Council of North America, and president of the International Institute of Islamic Thought in Herndon, Virginia. This address was translated from the original Arabic by Yusuf Talal DeLorenzo, IIIT Research Department. 
Throughout this century and most of the last, Muslims have taken it upon themselves to reconcile the western vision of life, humanity, and the universe with their own, or to reconcile the Islamic vision of the same with the precepts of the western vision. As a result, many practicing Muslims have inclined toward rationalizing whatever appears to challenge their constructs in this regard or to contradict their concepts of the universal nature of positivism and the secular paradigm. Thus we have seen some equating the jinn with microbes, or angels with electrons, or prophets with geniuses! To such apologists, Islam touches only the "spiritual" life of its followers and thus may be considered another link in the rusty chain of "religions." For such "thinkers," the concepts of shürä and khiläfah correspond with western ideals of democracy and republicanism, while socialism and social justice are represented by zakah!

In short, the crisis of the Muslim mind and the absence of intellectual creativity or an ijtihad mentality have stymied the development of a contemporary Islamic paradigm of knowledge. Rather, the entire matter has been ignored, with the result that the distinguishing features of such a paradigm have yet to be identified. Moreover, in the Muslim world there are two streams of education. The first stream, which produces the Muslim world's technical experts, scientists, social scientists, intellectuals, and makers of public opinion, is based on and functions completely within the secular positivist paradigm. The second stream, perhaps more akin to a backwater, is the religious education stream. However, the sources of this stream owe more to tradition than to any understanding of the parameters of a truly Islamic paradigm of knowledge. For centuries, this stream of education has been able to do no more than repeat itself, by offering the same commentary on the same texts in the same disciplines of fiqh, ușül, hadith, and tafsìr.

The Islamization of knowledge undertaking seeks to develop an Islamic paradigm of knowledge that will serve as an alternative to the secular positivist paradigm that presently dominates the arts and sciences. Such an alternative combines Islamic and universalistic perspectives; addresses the intellectual and conceptual problems of all humanity, not just of Muslims; and includes a tawhìd-based reconstruction of the concepts of life, humanity, and the universe. What, then, is this Islamic paradigm of knowledge, and what are its basic components?

\section{Tawhīd}

The Islamic view of knowledge takes as its starting point the concept of tawhid (unicity) in the divinity and attributes of God. It is on the foundation of tawhid that the entire edifice of the Islamic paradigm of knowledge stands. The epistemological aspects of tawhid are manifested via God's attribute of absolute knowledge and His teaching humanity that 
which it did not know. Moreover, God created within humanity the capacity to learn, teaching Adam "the names" of things, endowing human beings with the aptitude to read and write, and instilling within them a natural sense of curiosity about themselves and their surroundings. He also sent messengers to present His revelation and explain, by means of scripture, all matters connected to the unseen, thus allowing human beings to expend their energies on making sense of the physical world, harnessing its power for the common good, uncovering its laws and mysteries, and developing methodologies for dealing with revelation.

\section{Revelation}

Both the Qur'an and the Sunnah represent sources of revealed knowledge that complement the natural universe. In addition, revelation may be taken as a creative source of belief, thought, worldview, and conceptualization. Revelation also gives order to establish human concepts, clarifies the relationships between God, humanity, and the universe, and then regulates these in such a way as to develop an integrated tawhid-based society. The place of the Sunnah is to clarify and elaborate on the Qur'anic epistemic methodology through linking the prophet's example and the values of the Qur'an so that these may be applied to the actuality of changing circumstances. By means of this methodology, humanity may transcend the dilemma of the relative and the absolute, and the real and the ideal.

In addition to revelation as a source of knowledge, there are other sources and means, such as reason, the senses, intelligence, intuition, and experience (including experimentation and observation). The Islamic paradigm of knowledge augments its sources with a number of principles and fundaments that are essential to its comprehensive and encompassing nature. Among these are khiläfah (stewardship) and amänah (responsibility for society) as the guiding factors in determining the meaning of life for humanity, a worldview that regards this world and the next as a single continuum, and a belief that intellectual activity is a religious and social responsibility for which the individual may be rewarded or punished. A very close relationship exists between knowledge and values, which lends to knowledge the attribute of purposefulness and, in turn, makes individuals responsible for distinguishing between useful and useless knowledge. At the same time, the Islamic paradigm of knowledge lends itself to academic activity at various levels. The Prophet, for example, once said, "Be a scholar or a student, but beware of the third category (ignorance), for that leads to destruction." In this way, the spread of knowledge was assured because no individual or class could claim a monopoly over it.

The Islamic paradigm enjoys a harmonious relationship with human nature (fitrah), which enables human beings to erect certain intellectual 
standards. It is with this context in mind that we can understand the saying: "Question your own heart (and rely on what it tells you), even if the so-called authorities tell you something else." This paradigm also includes many fundamental characteristics that can be of use in bringing about a truly global and universalistic human outlook. Among these are humanity, utility, harmony, positivity, stability, globality, universality, methodology, intermediacy, comprehensiveness, guidance, spirituality, expansiveness, and openness.

Owing to the linkage that exists in the fine relationship between God and humanity, between this world and the next, and between the religious and the worldly life, this paradigm is not subject to closure. This explains, in turn, how the Islamic paradigm can simultaneously be selective and comprehensive and how it can adapt itself to whatever is positive and avoid whatever is negative in knowledge. Ultimately, all of this will result in the establishment of an intellectual criteria that will link knowledge with values and with higher purposes and universal principles.

The positivistic secular paradigm boasts of its analytical proficiency, which indeed it is able to do quite well. However, analysis and deconstruction are not to be undertaken merely for their own sake, but rather to comprehend what has been analyzed and to correct what has gone wrong. Although the secular paradigm has made its analysis and has deconstructed its subjects, it has proven itself to be extremely limited in its utility because it has been unable to produce a program of successful reconstruction. While it has been effective in explaining situations, the explanation is only as good as the intellectual goals it serves. Thus, when the goals are limited or restricted to certain parameters of inquiry, the benefits to be had from positivistic explanations must necessarily be limited as well.

The oneness of humanity is a dimension that endows the Islamic paradigm of knowledge with the ability to effect constructs. God states in the Qur'an: "O you people! Verily have We created you from male and female, and have made you into nations and tribes, so that you might come to know one another. Verily the noblest of you in the sight of God is the one who is most heedful among you" (49:13); "He has created you out of a single soul, and from it He fashioned its mate" (39:6); and "Nor have We sent you (O Prophet!) save as [an evidence of Our] grace towards all the worlds" (21:107). Moreover, the Islamic perspective on the essential oneness of the universe further endows its paradigm with the ability to develop constructs.

\section{Purifying Methodology from Negative Elements}

The Islamic paradigm of knowledge protects methodology from speculation and whim. As a result, the Islamic creed can serve as protection from all such elements, for it leaves no scope for the acceptance of any- 
thing originating outside the ecclesiastically established sources. This is important, for even up until our own time humanity has been unable to rid itself or move beyond speculation, whim, caprice, and the like.

According to the Islamic paradigm of knowledge, human knowledge is enriched by knowlege of the divine, so that the individual is always aware of God's assistance and never has the sense of being left entirely to his/her own devices. Therefore, the attitude so haughtily touted by the secular paradigm, that the unseen has no epistemological value, is utterly rejected by the Islamic paradigm. Instead, the Muslim is fortified by the confidence that comes from reliance on the two most important sources of knowledge: revelation and the universe.

The Muslim's association with prophecy and its revelational legacy adds to his/her intellectual orientation a dimension of universality, humanity, and ethics. In addition, tawhid and the acceptance of the divine as a source of knowledge prevent Muslims from placing undue dependence upon the self (with its vain and overweening tendencies) and from seeking to hide knowledge from others. A further benefit of tawhid is that it purifies espistemological issues through the constant scrutiny and revision demanded by the dynamic of ijtihad and the tawhìdi rejection of any ultimate other than God. Thus, whatever is considered final by an individual or an entire generation of Muslims will not necessarily remain the final word for another individual or a following generation; others will always have the right to open or reopen any issue for further consideration, refinement, or rejection.

The dimension added by tawhìd to the Islamic paradigm of knowlege also averts the misuse of knowledge as power, for the paradigm includes the concept of a participatory and sharing community of knowledge that, by nature, precludes monopolization and elitism. The fundamental sources of knowledge are available to everyone, as are the methodological steps necessary for dealing with them. Furthermore, the connection between knowledge and values precludes any notion of a need to adhere to established epistemological norms and thus opens the door to continued examination and analysis. All of this, in turn, ensures that people will not live under the impression that they have found all the answers while, at the same time, possessing knowledge of little more than the outward aspects of the life of the present world.

The religious aspect of the paradigm also ensures that knowledge is linked with every aspect of human life, be it past, present, future, or in the hereafter, and that it is capable of contemplating eternal truths and endowing them with greater, purer, and more comprehensive relevance. It is this aspect that ensures that knowledge remains elevated and that it never succumbs to the baser inclinations, artistic or otherwise. All of this springs from humanity's role as khalifah (steward), of 
natural dignity, humanness, trust, and responsibility for improving society.

The above should be viewed as no more than brief preliminary remarks intended to explain the differences between the Islamic and the secular positivistic paradigms of knowledge. It should be possible, however, to base more intensive, comprehensive, and detailed studies on what has been outlined here. 